Volume 3

Number 4 Critical Perspectives on Marketing

from Japan - Part 2

Article 1

2018

\title{
Critical Thinking from Japan: Additional Perspectives
}

Masaaki Takemura

Meiji University

Nikhilesh Dholakia

University of Rhode Island

Follow this and additional works at: https://digitalcommons.uri.edu/mgdr

Part of the Anthropology Commons, Economics Commons, Japanese Studies Commons, Marketing Commons, Other Business Commons, and the Sociology Commons

\section{Recommended Citation}

Takemura, Masaaki and Dholakia, Nikhilesh (2018) "Critical Thinking from Japan: Additional Perspectives," Markets, Globalization \& Development Review. Vol. 3: No. 4, Article 1.

DOI: 10.23860/MGDR-2018-03-04-01

Available at: https://digitalcommons.uri.edu/mgdr/vol3/iss4/1

This Editorial is brought to you for free and open access by DigitalCommons@URI. It has been accepted for inclusion in Markets, Globalization \& Development Review by an authorized editor of DigitalCommons@URI. For more information, please contact digitalcommons-group@uri.edu. 
Critical Thinking from Japan: Additional Perspectives

Cover Page Footnote

The core ideas in this editorial are from the first editor. The second editor has provided general background and English language editing. 


\section{Markets, Globalization \& Development Review}
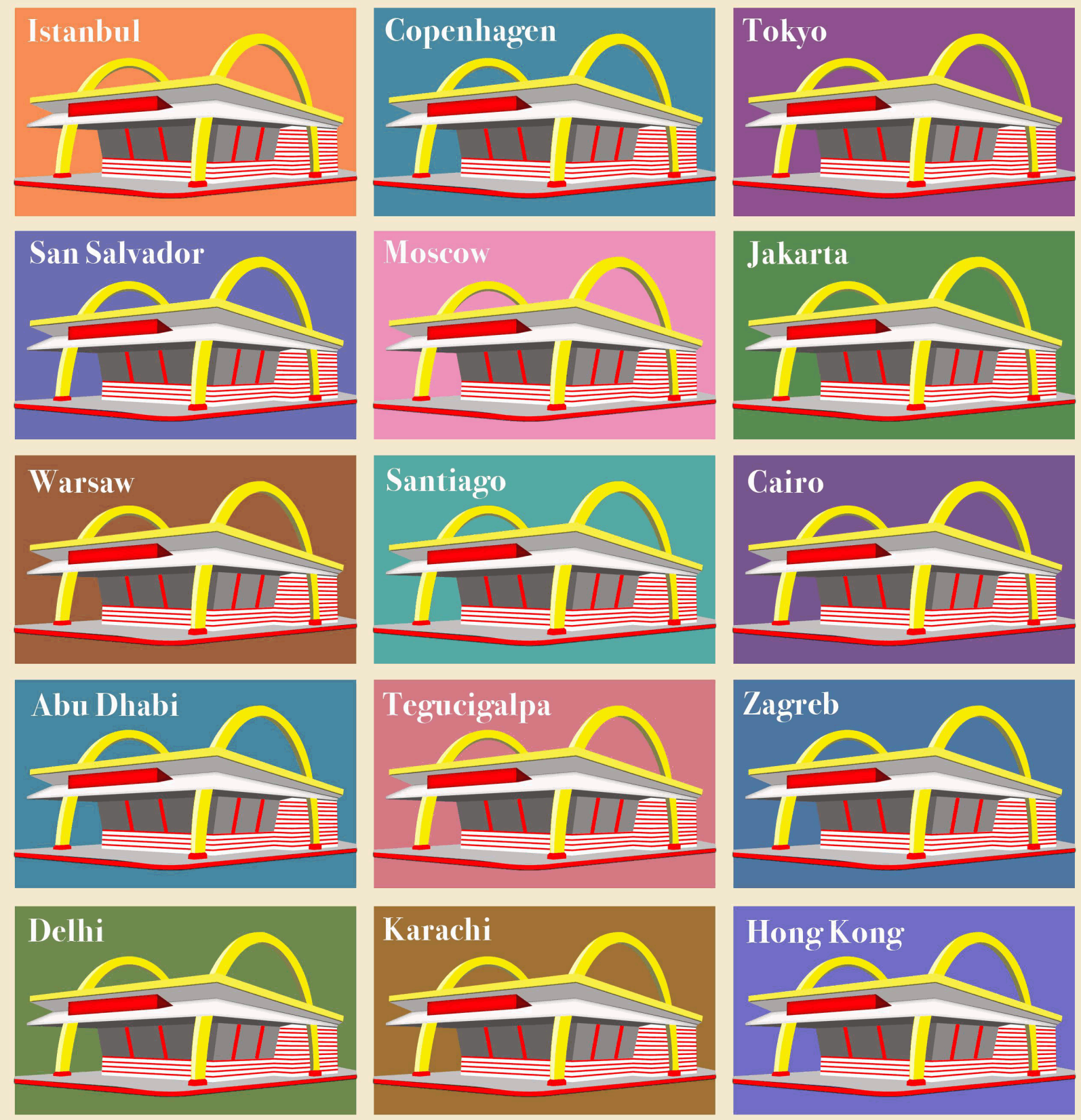

This editorial is available in Markets, Globalization \& Development Review: https://digitalcommons.uri.edu/mgdr/ vol3/iss $4 / 1$ 


\section{Critical Thinking from Japan: Additional Perspectives}

\section{Introduction}

The first MDGR special issue on Japan introduced some aspects of critical marketing thinking in Japan (Takemura and Dholakia 2018). In that special issue, the contribution by Kazuo Usui showed that several Japanese academicians, especially prior to 2000 , were influenced by the critical marketing paradigm of Fujiya Morishita (Usui 2018). Morishita (1969) formulated his framework about distribution sciences (i.e., series of selling and buying actions of merchants) based on Marx's concepts about the movement of capital. Morishita explored how the distribution system in Japan evolved, from a merchants-dominated structure to a modern, large enterprise-dominated structure. One important, but implicit, assumption in his framework was the law of historical development, with the emergence of 'marketing', as we know it, an inevitability in the advanced phase of capitalism. This framework fascinated several Japanese scholars because Japan, until very late $19^{\text {th }}$ century, had been a relatively underdeveloped country; and then in just a few decades - zoomed ahead to the ranks of advanced and modern capitalist economies.

\section{New Articles: A Critical Practitioner, Social Media, Moribund Education}

In the 21st century, new critical marketing academicians and practitioners in Japan are stepping beyond the Morishita legacy. The first article in the first Japan issue, on Morishita, was by the well-known Japanese scholar of marketing history, Kazuo Usui. In the second issue, also Kazuo Usui (2018a) has the first article. He presents a Japanese entrepreneur's biography, a man who wore multiple hats - including that of being a critical marketing scholar. Usui focuses on Seiji Tsutsumi, who served as the president of SAISON group, as well as - wearing a scholarly hat - developed critical and radical thought on the distribution industry and its development in the 1980s. SAISON group was one of the biggest retail companies with a variety of service companies such as department stores, specialty stores, hotels, restaurants, travel agency, real estate projects, and so on. Through the 1990s, SAISON group was applauded for providing new type of consumption experiences and achieved noteworthy performance.

Seiji Tsutsumi was so talented that not only did he manage a retail empire, but also did creative writing under a pseudonym and was awarded as a poet and a fiction writer. He was a member of the Communist Party and even earned a doctorate in philosophy degree. 
During his time as the retail group president, he retained a critical attitude to contemporary consuming society and marketing of big enterprises. While many books and anecdotes about Tsutsumi's achievements have been published, in the MGDR article that follows, Kazuo Usui provides additional and new perspectives in terms of Tsutsumi's critical thinking on marketing and consumer culture.

According to Tsutsumi, previous discussions of retail industry (and distribution service industry, more generally) were based on channel leadership, that is, on who could dominate and have pricing power. Tsutsumi, on the other hand emphasized the changing paradigm of industrial society, in which people should get back to the fundamental meaning of consumption. With these critical thoughts about modernized capitalism (specifically, mass-production and mass-consumption), Tsutsumi indeed modified retail practices - he developed new types of department stores and new format of retail shops. These stores insisted on artistic meaning and symbolism of goods rather than functions, utilities, fashion and other benefits that retail goods typically provide. His approach to new types of retail industry, for some period, certainly succeeded and his prominent achievements were applauded during the 1980s. The retail empire mostly vanished before the dawn of the $21 \mathrm{st}$ century - but the iconic Muji artistic store survives, with some international branches.

Our second article, in this second special issue on Japan, focuses on Hatsune Miku, a new digital music experience in Japan. Hatsune Miku is essentially a software, but with the humanoid screen form of a 16-year-old girl with long, turquoise twintails. The article by Hajime Kobayashi and Takashi Taguchi introduces the development and evolution of Hatsune Miku and discusses, from a critical angle, some limitations of it (Kobayashi and Taguchi 2018).

Technically, Hatsune Miku is a vocal synthesis oscillator, VOCALOID, developed by YAMAHA in 2003. As is easy to guess, VOCALOID is onomatopoeias of vocal and android (andro: man in Greek). Hatsune Miku was marketed in 2007 as a packaged software for PC by Crypton Future Media. In the early stage of its introduction, it was widely believed that Hatsune Miku would be used for chorus and background vocals. Contrary to these early expectations, Hatsune Miku sold more than 4000 copies in the first two weeks, compared to average sales of such desktop music (DTM) software at the rate of 1000 copies in a year. The article analyzes this sales success in the early stage in terms of creating a place to exhibit, on internet social media, the works (products) created by the more advanced users.

While Hatsune Miku achieved huge popularity, this popularity was constrained in many ways. There are mainly two reasons. The first one is the distinction between advanced users and mere listener-viewers. Hatsune Miku is essentially an imaginary "person" 
(Anime-style character), and the dominant listener-viewers are Anime-following nerds. This aspect filters out the larger, wider base of mass customers. The second issue is about copyright. Making music using Hatsune Miku is basically a form of imitation from existing music. The MGDR article points out that a type of creative-commons license was created in Japan, to facilitate such adaptive imitation. Of course, a few of the pieces using the Hatsune Miku technology are originals, but this is essentially a "mashup" software. Those who can compose really distinctive original music by themselves are unlikely to use this software.

The article by Kobayashi and Taguchi (2018) echoes - in the Japanese context - some of the contested and contentious aspect of online platforms, as other MGDR authors have alluded to in the special issue on 'Virtual Platforms' (Ozgun 2018). Hatsune Miku users, even the advanced ones, are constrained in their creativity for narrative creation within the framework of the platform. The result is a form of "managed creativity", and the technology platform does not create a high-participation media space and a rosy democratic future.

The third article in this special issue (Takemura 2018) revisits the correspondence principle and the associated theory by Bowels and Gintis (1976). The correspondence theory became famous around 1970s for revealing the contradictions of the American education system. It exposed that most of the lofty and noble missions and expected functions of the schooling system - integrative, egalitarian, and developmental; along the lines of progressive education ideas of Dewey - worked, in practice, in dysfunctional ways. The reason why this dysfunction happened is that there were attempts to have a structural correspondence of social relations between education and production. Bowles and Gintis argued that schooling system could not work integrally under the enterprise capitalism. Capitalism is the cause of social and economic inequality, and schooling system - rather than promoting lofty egalitarian goals - ultimately had to toe the capitalist agenda.

The MGDR article reviews the Bowles-Gintis ideas and discussions, and then turns to Japan, where all educational systems are dysfunctional in many respects. Insufficient numbers of pre-school nurseries have huge waiting lists. Mothers with jobs often have to turn to unregistered and unofficial nurseries. In elementary schools, teachers are too busy with bureaucratic 'make-work' to take care of students. Junior high and high schools still cannot find effective solutions to counter the scourge of bullying, ostracism and even tragic youth suicides. Universities face declining applications, due to falling birth rates in Japan. Some universities aggressively seek students from other Asian countries, but many cannot avoid the demographic challenge of shortage of applicants. 
In this article, the author suggests another problem in the Japanese education system, linked to the Bowles-Gintis correspondence principle and theory. Japanese corporate hiring customs integrate 'recruiting' themes into education from the 4th grade and such themes continue on, forcing even university students to adjust their attitudes and thoughts with the corporate recruiting culture. Students are, in effect, tossed about by companies' recruiting needs and timetables.

In Japan, there are entrenched expectations of both students' families and companies. No one in Japan can deny that the main purpose of graduation from university is to get a job, specifically (preferably) a job at a famous and branded company. Consequently, few students exhibit curiosity in their classes. As the article shows with some evidence, most students tolerate classes and lectures - and indeed score high on international tests. They obey - but do not respect or love - their teachers. No definitive conclusions can be drawn, but the paper initiates a discussion. A recent paper by Rikowski (2019), for example, offers the following overall thoughts:

- “... for Bowles and Gintis, teachers were little more than pawns for capital...merely preparing young people... for the work... fitting school leavers and college students into a capitalist labour market" (pp. 165-166).

- The alternative view focuses on "the value of "education for its own sake', education as a public good, and teachers as initiating young people and adults into forms of knowledge essential for individual and societal wellbeing" (p. 166).

- Rikowski hopes for (but does not, yet, offer) pathways to reach a stage "when conscious alternatives to capitalist education are generated (e.g. workers' educational cooperatives)... signalling a desire to leave capital behind when it comes to education" (pp. 166-67, emphasis original).

Our hope, from the viewpoints of this special issue and the MGDR editors, is that efforts and discussions would continue to seek such alternatives - to make education more than a tool for the (re)production of workers for capitalist enterprises.

\section{Reviews in this Special Issue}

We have one book review and a film review in this special issue. The book review introduces "ikigai", a specific and typical Japanese way of approaching the meaning of life. This book is an important achievement in that it is written in English, making the Japanese "ikigai" idea accessible outside Japan. Also, the book author is a technology specialist and media personality - she helped in the movie "Facebook" as a Japanese interpreter. Thus, she writes in a practical (and not overly 
philosophical) way.

The reviewer, Yasuko Takayama (2018), gives not only provides a detailed summary of "ikigai", but also elaborates on the multiple connotations of the term. Ikigai can refer to something that gives us joy in everyday life, an idea that connotes the purpose of working and the value of labor, and even an approach to making a 'bucket list' (even though the Japanese do not have this phrase). The reviewer also brings forth the ambiguousness and vagueness of defining "ikigai" to the Japanese, a concept which, despite all elaboration, remains ambivalent in many ways. Readers of this book review can glean the changing role of "ikigai" from this essay. There is a recent and resurgent new trend of meaning of life, "ikigai", in Japan and for the Japanese. For many decades, the Japanese people could not pursue "ikigai" because they were recovering from the ruination of World War II. The "ikigai" concept did not disappear but became dormant. From the the 1970s to the 1990s, Japan was applauded as a miracle economy - as evidenced by the "Japan as No.1" book by Vogel (1979). There was widespread admiration of Japanese management, included lifetime employment commitment, extensive on-the-job training, total quality management, and so on (Abegglen 1958). During these years, Japanese did not need to seek "ikigai"; it was given externally - by the 'miracle economy'.

After the 1990s, when the miracle period ended, Japan and Japanese have been still struggling with adapting to new world circumstances and are attempting to adjust inner systems and structures. The current phase is referred to variously as "the age of uncertainty", "the age of anxiety", and "the age of alternative facts"; and many such terms. People are searching for guiding principles. The contemporary Japanese tend to find ikigai in everyday life and tiny working episodes, and not as a powerful external object. The reviewer introduces the non-Japanese to the recent, nuanced - and ambivalent concepts of ikigai.

The last item in this special issue is a film review, of the animation movie "Isle of Dogs". Reviewer Soonkwan Hong (2018) introduces us to this animation movie on dogs - the central characters and their canine and human colleagues. While we can enjoy this movie from the technical animation perspective, Soonkwan Hong takes us deeper, in cinematic terms. He points to several "secret flavors and tropes" - hidden meanings of mise-en-scene. These range from Akira Kurosawa, the late lifetime Oscar-winner Japanese movie director; Hayao Miyazaki, a movie producer and a founder of Ghibli animation studio; and Hideaki Anno, animator and director of several Science Fiction animations, such as Evangelion; and so on. These cinematic devices are employed by director Wes Anderson to make the animated freak dogs humanlike, powerful, and generally happy.

The movie is constructed on a simple structure of a conquest 
story. A pet dog is banished to a remote island, its owner pursues in search. Multiple adventures, mishaps and a rebellion take place. The story, however, is allegorical at another level - implicitly describing the recent world trends of bigotry and attacks on "otherness". The reviewer brings in some insightful literature from postcolonial theory, to delve into the connotative aspects of this film.

Three contemporary and allegorical factors are discernible. The first one is fake news. This story began with narration that, long long ago, there was a war between dogs and dog-hater Kobayashi family. The mayor of the town Kobayashi still has hatred for and hostility toward dogs, and he develops a "dog-infecting disease" to eliminate dogs officially. The second allegorical aspect is pseudo-communication, or, "as-if-understandable communication". In the movie, dogs "spoke" with English subtitles, but humans spoke in Japanese. This subtly criticizes Japanese who cannot speak English well. Of course, the cinematic portrayal emphasized that dogs and people actually cannot communicate using languages - in the town ruled by Kobayashi. This "dis-communication" helped to further the hostility and the hatred. The movie shows that trusted communication between dogs and people is possible; and through this, the evil is eventually destroyed and the good folks - dogs, humans - save themselves. The last aspect is about extremist positions and decisions. The mayor was a paranoid extremist, and believed that eliminating dogs was the solution. He did not search for any other solution than killing the dogs (the metaphorical "other") with a virus, or exiling them. The reviewer links and compares this to the recent exclusion of, and hatred of, immigrants in Europe. The sanguine lesson, at the end, is that communication and coexistence can make the society fair, and happy.

\section{Concluding Comments}

This special issue on Japanese critical marketing study has multiple challenging themes and topics that are linked to Japanese way of thinking. The authors and reviewers offer perspectives that are insightful and critical. The editors - of the special issue and of MGDR would be happy if the two special issues could initiate further and broader discussions of Japanese economic and social systems.

A final and important digression: the MGDR editors and the editorial board and staff want to offer an important vote of thanks. This is the final issue of MGDR for which Murad Canbulut, the Managing Editor of MGDR, stays in this role. This is an important role at MGDR. When the manuscripts reach the near-final stage, Murad takes over and reviews everything meticulously, using MGDR Style Guide. He also ensures that references and citations adhere to the best bibliographic standards. What you see in the final PDF is the result of what we call 'Murad Magic'. The journal editors are immensely grateful for his 
services, are somewhat sad that he is stepping down from his MGDR role; but also very happy that he will be pursuing many exciting academic and other opportunities. From Volume 4 of MGDR, Rabia Bayer will take over this role. 


\section{References}

Abegglen, James C. (1958), The Japanese Factory: Aspects of Its Social Organization. Glencore, IL: Free Press.

Bowels, Samuel and Herbert Gintis (1976), Schooling in Capitalist America: Education Reform and the Contradictions of Economic Life. New York: Basic Books.

Hong, Soonkwan (2018), "Orientalism, Resistance or Global Harmony? Entangled Strands in the film Isle of Dogs", Markets, Globalization \& Development Review, 3 (4), Article 6.

Kobayashi, Hajime and Takashi Taguchi (2018), "Virtual Idol Hatsune Miku: Case Study of New Production/Consumption Phenomena generated by Network Effects in Japan's Online Environment", Markets, Globalization \& Development Review, 3 (4), Article 3.

Morishita, Fujiya (1969), Contemporary Economic Merchandise [Gendai Shogyo Keizairon], Tokyo: Yuhikaku. (in Japanese)

Ozgun, Aras (2018), "[Cntrl] + [Alt] + [Esc] ? Virtual Platforms as Spaces of Control and Contestation", Markets, Globalization \& Development Review, Vol. 3 (3), Article 1. https://doi.org/10.23860/MGDR-2018-03-03-01

Rikowski, Glenn (2019), "Education Crises as Crises for Capital”, Theory in Action, 12 (3). https://doi.org/10.3798/tia.1937-0237.1924

Takayama, Yasuko (2018), "Yukari Mitsuhashi, Ikigai: Giving every day meaning and joy (2018)", Markets, Globalization \& Development Review, 3 (4), Article 5.

Takemura, Masaaki (2018), "Education, Enterprise Capitalism, and Equity Challenges: The Continuing Relevance of the Correspondence Principle in Japan", Markets, Globalization \& Development Review, 3 (4), Article 4.

Takemura, Masaaki and Nikhilesh Dholakia (2018), "Japan and Critical Marketing Theory: Opening a Window", Markets, Globalization \& Development Review, Vol. 3 (1), Article 1. https://doi.org/10.23860/MGDR-2018-03-01-01

Usui, Kazuo (2018), "Critical Marketing in Japan: The Legacy of Fujiya Morishita", Markets, Globalization \& Development Review, 3 (1), Article 2, DOI: https://doi.org/10.23860/MGDR-2018-03-01-02

Usui, Kazuo (2018a), "A Critical Marketing Practitioner in Japan: Philosophy and Marketing Activities of Seiji Tsutsumi", Markets, Globalization \& Development Review, 3 (4), Article 2. 
Vogel, Ezra F. (1979), Japan as Number One: Lessons for America. Boston: Harvard University Press. 